\title{
Effect of packing factor and fine aggregate/total aggregate ratio on the development of self-compacting concrete
}

\author{
S V S Sankeerth ${ }^{1 *}$, Srinivasa Reddy $\mathrm{V}^{2}, S$ Shrihari ${ }^{3}$ and $C$ Rajashekar ${ }^{4}$ \\ ${ }^{1}$ M. Tech (Structural Engineering), Department of Civil Engineering, GRIET, Hyderabad, India. \\ ${ }^{2}$ Professor of Civil Engineering, GRIET, Hyderabad, India. \\ ${ }^{3}$ Professor of Civil Engineering, VJIT, Hyderabad, India. \\ ${ }^{4}$ Assistant Professor of Civil Engineering, JBIET, Hyderabad, India.
}

\begin{abstract}
This paper presents the effect of packing factor and fine aggregate/total aggregate ratio on the performance of the self-compacting concrete (SCC). A higher PF value would imply a greater amount of the coarse and fine aggregates used, thus, decreasing the content of binders in SCC. In this paper M30 grade plain SCC mixes are developed with the different combinations of packing factors (PF) (varying from1.12 to 1.18$)$ and fine to total aggregate ratios (s/a) $(0.50$ to 0.57$)$ and found that the PF \& s/a combinations of $1.12 \& 0.53$ and $1.14 \& 0.57$ are found to be optimum as these combinations gave maximum compressive strengths which can be attributed to high achievement of particle packing densities in SCC mixes. As PF increases powder content decreases and aggregate content increases requiring more paste to make the SCC mix workable. Less value $\mathrm{PF}$ will have high particle packing density yielding more strength due to improved microstructure of SCC mixes. At PF \& s/a combinations of $1.12 \& 0.53$ and $1.14 \& 0.57$, the workability of SCC mixes is superior because of high paste volume and less aggregate content.
\end{abstract}

\section{Introduction}

The Nan Su method's major consideration is that voids in loose aggregate are filled with paste and that aggregate packing is minimised. This approach distinguishes between loose packaging and packing that has been compacted. The void reduction is stated with a packing factor in the Nan Su method (PF). The $\mathrm{PF}$ that compares the apparent density of loosely packed aggregate to the apparent density of aggregate in a state of packing in SCC.

\section{SCC mix design guidelines}

The packing factor (PF) of aggregate is defined as the ratio of mass of aggregate of tightly packed state in SCC to that of loosely packed state. Clearly, PF affects the content of aggregates in SCC. A higher PF value would imply a greater amount of the coarse and fine aggregates used, thus, decreasing the content of binders in SCC. Consequently, its flowability, selfcompacting ability and compressive strength will be reduced. On the other hand, a low PF value would mean increased dry shrinkage of concrete. As a result, more binders are required, thus, raising the cost of materials. In addition, excess binders used would also affect the workability and durability of SCC. Therefore, it is important to select the optimal PF value in the mix design method so as to meet the requirements for SCC properties, and at the same time taking economic feasibility into consideration.

\section{Mix Design}

The proportioning of the SCC mix was first done using the Nan Su mix design principles. The M30 grade of plain self-compacting concrete (SCC) was used in this experiment for various combinations of packing factors (PF) ranging from 1.10 to 1.18 and fine aggregate to total aggregate ratios ( $\mathrm{s} / \mathrm{a}$ ratio) ranging from 0.5 to 0.57 . The packing factor and s/a ratio combinations are used to further modify the mix design. According to $\mathrm{Nan} \mathrm{Su}$, the characteristics that determine the mix proportion are packing factor, fine aggregate/total aggregate ratio, and powder content. The cement concentration, fly ash content, and fine aggregate/total aggregate ratio were calculated using

*Corresponding author: svssankeerth123@gmail.com 
Nan Su mix design principles. Fly ash is employed as a mineral admixture in this study, and it was created using an efficiency principle.

\section{Compressive Strength}

The value of uniaxial compressive stress attained when a material fails entirely is known as its compressive strength. The cube specimens of size 150 $\mathrm{mm}$ are examined in this study according to IS: $516-$ 1969 [Method of test for concrete strength]. Based on the realisation of EFNARC workability properties and required target strength, the best packing factor and s/a ratio combinations are identified. Table 4 shows the compressive strength of M30 grade PSCC mixes for various packing factor and s/a ratio combinations. Plain SCC mixes M30PSCC5 and M30PSCC10 with packing factor and s/a ratio combinations of $1.12 \&$ 0.53 and $1.14 \& 0.57$ have reached target compressive strengths, according to the results. As a result, the PF $\&$ s/a combinations $1.12 \& 0.53$ and $1.14 \& 0.57$ are thought to be the best for developing simple SCC mixtures of M30 grade.

Table 1. For various combinations of packing factor and s/a ratios, M30 Grade PSCC amounts were computed using the Nan

\begin{tabular}{|c|c|c|c|c|c|c|c|c|}
\hline Mix Type & PF & $\begin{array}{c}\text { s/a } \\
\text { ratio }\end{array}$ & $\begin{array}{c}\text { Cement } \\
\mathrm{kg}\end{array}$ & $\begin{array}{c}\text { Fly ash } \\
\text { Kg }\end{array}$ & $\begin{array}{c}\text { CA } \\
\mathrm{kg}\end{array}$ & $\begin{array}{c}\text { FA } \\
\mathrm{kg}\end{array}$ & $\begin{array}{c}\text { Water } \\
\text { L }\end{array}$ & $\begin{array}{c}\text { SP } \\
\text { L }\end{array}$ \\
\hline M30PSCC1 & 1.12 & 0.50 & 306.61 & 113.78 & 847.27 & 820.12 & 218.44 & 7.99 \\
\hline M30PSCC2 & 1.14 & 0.50 & 306.61 & 93.77 & 862.40 & 834.77 & 211.07 & 7.69 \\
\hline M30PSCC3 & 1.16 & 0.50 & 306.61 & 73.75 & 877.53 & 849.41 & 203.70 & 7.38 \\
\hline M30PSCC4 & 1.18 & 0.50 & 306.61 & 53.74 & 892.66 & 864.06 & 196.33 & 7.08 \\
\hline M30PSCC5 & 1.12 & 0.53 & 306.61 & 114.75 & 787.96 & 877.53 & 218.80 & 8.01 \\
\hline M30PSCC6 & 1.14 & 0.53 & 306.61 & 94.746 & 802.03 & 893.20 & 211.43 & 7.71 \\
\hline M30PSCC7 & 1.16 & 0.53 & 306.61 & 74.748 & 816.10 & 908.87 & 204.07 & 7.40 \\
\hline M30PSCC8 & 1.18 & 0.53 & 306.61 & 54.75 & 830.18 & 924.54 & 196.71 & 7.10 \\
\hline M30PSCC9 & 1.12 & 0.57 & 306.61 & 115.72 & 728.65 & 934.94 & 219.15 & 8.02 \\
\hline M30PSCC10 & 1.14 & 0.57 & 306.61 & 95.72 & 741.66 & 951.63 & 211.79 & 7.72 \\
\hline M30PSCC11 & 1.16 & 0.57 & 306.61 & 75.74 & 754.67 & 968.33 & 204.43 & 7.41 \\
\hline M30PSCC12 & 1.18 & 0.57 & 306.61 & 55.76 & 767.69 & 985.02 & 197.08 & 7.11 \\
\hline
\end{tabular}

Table 2. Quantities of M30 Grade PSCC after numerous trail mixes with varying packing factors and s/a ratios

\begin{tabular}{|c|c|c|c|c|c|c|c|c|}
\hline Mix Type & PF & $\begin{array}{c}\text { s/a } \\
\text { ratio }\end{array}$ & $\begin{array}{c}\text { Cement } \\
\mathrm{kg}\end{array}$ & $\begin{array}{c}\text { Fly ash } \\
\text { Kg }\end{array}$ & $\begin{array}{c}\text { CA } \\
\mathrm{kg}\end{array}$ & $\begin{array}{c}\text { FA } \\
\mathrm{kg}\end{array}$ & $\begin{array}{c}\text { Water } \\
\mathrm{L}\end{array}$ & $\begin{array}{c}\text { SP } \\
\mathrm{L}\end{array}$ \\
\hline M30PSCC1 & 1.12 & 0.50 & 258.28 & 173.40 & 848.40 & 794.06 & 223.11 & 7.88 \\
\hline M30PSCC2 & 1.14 & 0.50 & 258.28 & 155.88 & 863.55 & 808.20 & 216.34 & 7.58 \\
\hline M30PSCC3 & 1.16 & 0.50 & 258.28 & 138.48 & 878.70 & 822.44 & 209.58 & 7.37 \\
\hline M30PSCC4 & 1.18 & 0.50 & 258.28 & 121.08 & 893.85 & 836.58 & 202.81 & 7.07 \\
\hline M30PSCC5 & 1.12 & 0.53 & 258.28 & 175.62 & 876.83 & 509.45 & 115.50 & 7.88 \\
\hline M30PSCC6 & 1.14 & 0.53 & 258.28 & 158.22 & 892.49 & 513.13 & 112.01 & 7.58 \\
\hline M30PSCC7 & 1.16 & 0.53 & 258.28 & 140.82 & 908.14 & 516.92 & 108.48 & 7.37 \\
\hline M30PSCC8 & 1.18 & 0.53 & 258.28 & 123.48 & 923.80 & 520.61 & 104.99 & 7.07 \\
\hline M30PSCC9 & 1.12 & 0.57 & 258.28 & 177.84 & 905.26 & 224.83 & 7.88 & 7.88 \\
\hline M30PSCC10 & 1.14 & 0.57 & 258.28 & 160.56 & 921.42 & 218.06 & 7.68 & 7.58 \\
\hline M30PSCC11 & 1.16 & 0.57 & 258.28 & 143.16 & 937.58 & 211.39 & 7.37 & 7.37 \\
\hline M30PSCC12 & 1.18 & 0.57 & 258.28 & 125.88 & 953.74 & 204.63 & 7.17 & 7.07 \\
\hline
\end{tabular}


Table 3. Fresh properties for M30 Plain SCC mixes

\begin{tabular}{|c|c|c|c|c|c|c|c|c|}
\hline \multirow[b]{2}{*}{ Mix Type } & \multirow[b]{2}{*}{$\begin{array}{c}\text { Fly } \\
\text { Ash \% } \\
\text { bwp }\end{array}$} & \multirow[b]{2}{*}{$\begin{array}{c}\text { Paste } \\
\text { volume }\end{array}$} & \multicolumn{6}{|c|}{ Fresh properties } \\
\hline & & & 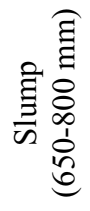 & 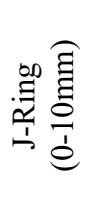 & 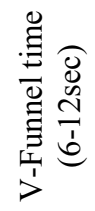 & 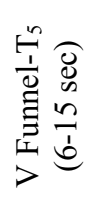 & 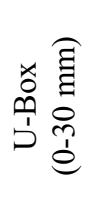 & 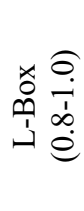 \\
\hline M30PSCC1 & 40.17 & 28.75 & 732 & 5 & 7 & 10 & 23 & 0.92 \\
\hline M30PSCC2 & 37.64 & 27.62 & 712 & 8 & 9 & 12 & 25 & 0.90 \\
\hline M30PSCC3 & 34.90 & 26.51 & 702 & 9 & 9 & 13 & 28 & 0.88 \\
\hline M30PSCC4 & 31.92 & 25.40 & 682 & 10 & 11 & 14 & 30 & 0.84 \\
\hline M30PSCC5 & 40.47 & 28.67 & 752 & 5 & 7 & 9 & 21 & 0.93 \\
\hline M30PSCC6 & 37.99 & 27.61 & 732 & 8 & 8 & 12 & 23 & 0.91 \\
\hline M30PSCC7 & 35.28 & 26.54 & 717 & 9 & 9 & 13 & 26 & 0.89 \\
\hline M30PSCC8 & 32.34 & 25.48 & 697 & 10 & 10 & 14 & 29 & 0.86 \\
\hline M30PSCC9 & 40.78 & 28.56 & 772 & 4 & 7 & 9 & 19 & 0.94 \\
\hline M30PSCC10 & 38.33 & 27.59 & 752 & 7 & 8 & 12 & 21 & 0.92 \\
\hline M30PSCC11 & 35.66 & 26.59 & 732 & 8 & 9 & 13 & 24 & 0.90 \\
\hline M30PSCC12 & 32.77 & 25.59 & 712 & 10 & 10 & 13 & 28 & 0.88 \\
\hline
\end{tabular}

Table 4. Optimum PF and s/a ratio combinations for M30 grade PSCC mixes

\begin{tabular}{|c|c|c|c|}
\hline Mix Type & PF & $\begin{array}{c}\text { s/a } \\
\text { ratio }\end{array}$ & $\begin{array}{c}\text { Compressive Strength (MPa) } \\
\text { at 28 days }\end{array}$ \\
\hline M30PSCC1 & 1.12 & 0.50 & 34.23 \\
\hline M30PSCC2 & 1.14 & 0.50 & 34.21 \\
\hline M30PSCC3 & 1.16 & 0.50 & 32.09 \\
\hline M30PSCC4 & 1.18 & 0.50 & 29.86 \\
\hline M30PSCC5 & $\mathbf{1 . 1 2}$ & $\mathbf{0 . 5 3}$ & $\mathbf{4 0 . 3 5}$ \\
\hline M30PSCC6 & 1.14 & 0.53 & 36.12 \\
\hline M30PSCC7 & 1.16 & 0.53 & 30.08 \\
\hline M30PSCC8 & 1.18 & 0.53 & 29.87 \\
\hline M30PSCC9 & 1.12 & 0.57 & 27.98 \\
\hline M30PSCC10 & $\mathbf{1 . 1 4}$ & $\mathbf{0 . 5 7}$ & $\mathbf{4 1 . 0 3}$ \\
\hline M30PSCC11 & 1.16 & 0.57 & 35.05 \\
\hline
\end{tabular}

\section{Conclusions}

Based on the results reported in this research work and key findings during the experimental investigations, the following conclusions are drawn:

1. As per the Nan Su mix design principles, M30 grade plain SCC mixes are developed with various combinations of packing factors $(\mathrm{PF})$ (ranging from 1.12 to 1.18 ) and fine to total aggregate ratios (s/a) (0.50 to 0.57$)$ subject to meeting the EFNARC flow standards..

2. The PF \& s/a combinations of $1.12 \& 0.53$ and $1.14 \& 0.57$ were found to be the most effective, resulting in the highest compressive strengths, which can be due to the high particle packing densities achieved in SCC blends.

3. As PF increases powder content decreases and aggregate content increases requiring more paste to make the SCC mix workable. Less value PF will have high particle packing density yielding more strength due to improved microstructure of SCC mixes.

4. Because of the large paste volume and low aggregate concentration, the workability of SCC mixes is improved for PF \& s/a combinations of $1.12 \& 0.53$ and $1.14 \& 0.57$.

5. SCC ability to flow is reduced with packing factors 1.16 and 1.18 with s/a ratios of 0.50 to 0.57 , owing to a lack of paste content, which 
causes the concrete to appear harsh and necessitates the use of more water and chemical admixtures to make it workable. Concrete tends to bleed when more water is added, which might reduce compressive strength.A higher value of packing factor (PF) indicates the larger aggregate content with less availability of powder content and will have less flow ability. So higher the PF, workability is reduced which can be enhanced with the usage of high fly ash content subjected to realization of desired strength.

6. The optimum PF and s/a ratio combination gives comparatively better particle packing density in SCC mixes. Better particle packing density enhances the microstructure of SCC mix subsequently more strength and durability can be achieved.

\section{References}

1. T.Srinivas and M. Abinay Raj, Int. J. of Eng.and Adv. Tech. (IJEAT), ISSN: 2249 - 8958, Volume-8 Issue-6 (2019)

2. T.srinivas and P. Manoj Anand, Int. J. of Innov. Tech. and Explor. Eng.g (IJITEE), ISSN: 22783075, Volume-8 Issue-12 (2019)

3. T.Srinivas and G. Sukesh Reddy, Int. J. of Eng.and Adv. Tech. (IJEAT), ISSN: 2249 8958, Volume-9 Issue-1 (2019)

4. T.Srinivas and R. N. Koushik, Int. J. of Innov. Tech. and Explor. Eng.g (IJITEE), ISSN: 22783075, Volume-8 Issue-12 (2019), PP 112-117.

5. K. Sai Gopi, Dr. T. Srinivas and S. P. Raju V, E3S Web of Conferences ICMED 184, 01084GRIET, 28-29 (2020)

6. M. Kavitha, P. B. Bobba and D. Prasad, 2016 IEEE 7th Power India International Conference (PIICON), 2016, pp. 1-6

7. Jagannadha Kumar, M.V., Jagannadha Rao, K., Dean Kumar, B., Srinivasa Reddy, V., Int. J. of Civil Eng. and Tech., 9(7), pp. 1133-1141 (2018)

8. Ganta, J.K., Seshagiri Rao, M.V., Mousavi, S.S., Srinivasa Reddy, V., Bhojaraju, C., Structures 28, pp. 956-972 (2020)

9. M. Kavitha, P. B. Bobba and D. Prasad, 2016 IEEE 6th International Conference on Power Systems (ICPS), 2016, pp. 1-6

10. Naidu, K.S.S.T., Rao, M.V.S., Reddy, V.S., Int. J. of Innov. Tech. and Explor. Eng.g (IJITEE), 8(9 Special Issue 2), pp. 641-642 (2019)

11. Chandana Priya, C., Seshagiri Rao, M.V., Srinivasa Reddy, V., Int. J. of Civil Eng. and Tech., 9(11), pp. 2218-2225 (2018)

12. Satya Sai Trimurty Naidu, K., Seshagiri Rao, M.V., Srinivasa Reddy, V., Int. J. of Civil Eng. and Tech., 9(11), pp. 2383-2393 (2018)

13. Supriya, Y., Srinivasa Reddy, V., Seshagiri Rao, M.V., Shrihari, S., Int. J. of Rec. Tech. and Engi., 8(3), pp. 5381-5385 (2019)
14. Kotkunde, N., Krishna, G., Shenoy, S.K., Gupta, A.K., Singh, S.K. International Journal of Material Forming, 10 (2), pp. 255-266 (2017)

15. Govardhan, D., Kumar, A.C.S., Murti, K.G.K., Madhusudhan Reddy, G. Materials and Design, 36, pp. 206-214. (2012)

16. Kumar, P., Singhal, A., Mehta, S., Mittal, A. Journal of Real-Time Image Processing, 11 (1), pp. 93-109. (2016)

17. Raghunadha Reddy, T., Vishnu Vardhan, B., Vijayapal Reddy, P. International Journal of Applied Engineering Research, 11 (5), pp. 30923102 (2016)

18. M. Vaishnavi and P. B. Bobba, 2019 IEEE 5th International Conference for Convergence in Technology (I2CT), 2019, pp. 1-6

19. Hussaini, S.M., Krishna, G., Gupta, A.K., Singh, S.K. Journal of Manufacturing Processes, 18, pp. 151-158 (2015)

20. K. Satyanarayana, A. V. Gopal, and P.B. Babu, Proceedings of the Institution of Mechanical Engineers, Part C: Journal of Mechanical Engineering Science, 228(1), 152 (2014) 